\title{
Kearifan Lokal dalam Kumpulan Puisi Kidung Cisadane Karya Rini Intama (Kajian Ekokritik Sastra)
}

\author{
Endang Sulistijani \\ Universitas Indraprasta PGRI \\ Endang711@yahoo.co.id
}

\begin{abstract}
This study aims to describe the local wisdom contained in the collection of Kidung Cisadane poem by Rini Intama. The reason for the selection of this research object because in this collection of poetry is not only presented values that are considered as the ideal reference standard of human behavior in life as a social creature, but also as an ecological creature. The method used in this research is the ecocritical method of literature with the model of environmental literature review and model of ethical studies. A study of ecological literature in eco-criticism can construct literary faces in local wisdom, while ethical perspective studies in ecocritical studies can describe the values of environmental wisdom. With the second model of the study, the ecological and cultural dimensions that have been lacking in full attention in literature can be further enhanced. In addition, in line with the development of the times, literature always voiced both cultural and ecological aspects.
\end{abstract}

Keywords: local wisdom, poetry collection, ecocritical literature, environmental literature review, ethical studies

\section{Intisari}

Penelitian ini bertujuan untuk mendeskripsikan kearifan lokal yang terdapat dalam kumpulan puisi Kidung Cisadane karya Rini Intama. Alasan pemilihan objek penelitian ini karena dalam kumpulan puisi ini tidak hanya disajikan nilai-nilai yang dianggap sebagai acuan standar ideal perilaku manusia dalam kehidupannya sebagai makhluk sosial, tetapi juga sebagai makhluk ekologis. Metode yang digunakan dalam penelitian ini adalah metode ekokritik sastra dengan model kajian sastra lingkungan dan model kajian etis. Kajian berprespektif sastra lingkungan dalam ekokritik dapat mengonstruksi wajah sastra dalam kearifan lokal, sedangkan kajian berprespektif etis dalam telaah ekokritik dapat mendeskripsikan nilai-nilai kearifan terhadap lingkungan. Dengan model kedua kajian tersebut, dimensi ekologis dan budaya yang selama ini kurang mendapat perhatian penuh dalam karya sastra dapat semakin ditingkatkan. Selain itu, sejalan dengan perkembangan zaman, sastra senantiasa menyuarakan aspek kultural sekaligus ekologinya.

Kata Kunci: kearifan lokal, kumpulan puisi, ekokritik sastra, kajian sastra lingkungan, kajian etis 


\section{Pendahuluan}

Aspek alam sudah lama menjadi objek yang diperbincangkan pengarang dalam karya sastra, baik itu sekedar sebagai latar atau juga sebagai tema utama.Menurut Keraf (2010: 47) dalam teori etika lingkungan, manusia dipandang sebagai pusat sistem alam semesta. Manusia dan kepentingannya, dalam tatanan ekosistem, dianggap yang paling menentukan dalam kebijakan yang terkait dengan alam, baik secara langsung maupun tidak langsung. Segala sesuatu yang berada di alam semesta ini hanya akan mendapat nilai dan perhatian sejauh menunjang kepentingan manusia. Dengan demikian, alam dipandang sebagai objek, alat, dan sarana bagi pemenuhan kebutuhan dan kepentingan manusia.

Keterkaitan alam dengan karya sastra ini memunculkan suatu konsep ekologi sastra dalam perbincangan kritik sastra. Konsep tersebut dikenal dengan istilah ekokritik (ecocritism). Istilah ekokritik berasal dari bahasa Inggris ecocritism yang terbentuk dari kata ecology dan kata critic. Ekologi dapat diartikan sebagai kajian ilmiah tentang hubungan makhluk hidup (manusia, hewan, dan tumbuhtumbuhan) satu sama lain dan terhadap lingkungannya. Kritik adalah bentuk dan ekspresi penilaian tentang kualitas-kualitas baik atau buruk dari sesuatu (Harsono, 2008: 31).

Menurut Endraswara (2016: 5), "Ekologi sastra adalah ilmu ekstrinsik sastra yang mendalami masalah hubungan sastra dengan lingkungannya". Dalam kaitannya dengan kajian sastra, istilah ekologi dipakai dalam pengertian beragam. Pertama, ekologi yang dipakai dalam pengertian yang dibatasi dalam konteks ekologi alam. Kajian ekologi dalam pengertian pertama ini juga dikenal dalam dua ragam, yaitu kajian ekologi dengan menekankan aspek alam sebagai inspirasi karya sastra dan kajian ekologi yang menekankan pembelaan atau advokasi terhadap kerusakan lingkungan yang disebabkan oleh perbuatan manusia. Kedua, ekologi 
yang dipakai dalam pengertian ekologi budaya yang ditentukan oleh pola hidup dan perbedaaan karakteristik wilayah (Endraswara, 2016: 13).

Pada intinya ekokritik, sebagaimana dikemukakan oleh Glotfety (!996:xix) adalah kajian hubungan antara sastra dan lingkungan fisik, kajian sastra yang berpusat pada dunia (earth-centered). Kajian yang juga disebut sebagai kajian hijau tersebut antara lain memperbincangkan cara alam diwakili dalam puisi, cara menjelaskan ciri-ciri genre kesusastraan alam sekitar, cara krisis alam sekitar memasuki kesusastraan komtemporer, dan sebagainya. Menurut Garrard (2004:14) pengetahuan ekologi bukan hanya untuk melihat harmoni dan stabilitas lingkungan, tetapi juga untuk mengetahui sikap dan perilaku manusia. Oleh karena itu, menurutnya analisis ekokritik bersifat interdisipliner yang merambah disiplin ilmu lain, yaitu sastra, budaya, filsafat, sosiologi, psikologi, sejarah lingkungan, politik dan ekonomi, dan studi keagamaan.

Menurut Buell, sastra ekokritik mempunyai kriteria: (1) lingkungan bukanmanusia hadir tidak hanya sebagai sebuah bingkai, tetapi sebagai kehadiran yang menunjukkan bahwa sejarah manusia diimplikasikan dalam sejarah alam; (2) kepentingan manusia tidak dipahami sebagai satu-satunya kepentingan yang sah (legitimate); (3) akuntabilitas manusia terhadap lingkungan merupakan bagian dari orientasi etis teks, dan (4) beberapa pengertian lingkungan sebagai suatu proses bukan sebagai pengertian yang konstan atau suatu pemberian yang paling tidak tersirat dalam teks (Buell, 1995: 7-8).

Kerridge (1998) mengungkapkan bahwa ekokritik ingin melacak ide atau gagasan tentang lingkungan dan representasinya, bagaimana nilai-nilai kearifan lingkungan itu. Oleh karena itu, model kajian ekokritik ini mencakup model kajian sastra lingkungan yang meliputi kajian pastoral dan apokaliptik serta model kajian etis yang mengandung kearifan lokal.

Teks ekokritik memiliki ciri yaitu mengandung ciri pastoral dan berisi narasi apokaliptik. Secara spesifik, pastoral adalah tradisi sastra tentang pelarian dari kota 
ke desa yang awalnya terdapat di Alexandria Kuno dan menjadi bentuk kunci puitika di Eropa selama Masa Renaissans. Secara umum, pastoral adalah sastra apa saja yang mendeskripsikan desa dengan mengontraskannya secara implisit dan eksplisit dengan kota. Selain itu, bentuk pastoral juga dapat dilihat dari sudut pandang pembaca atau pendengar. Dari sudut pandang ini, pastoral merupakan bentuk pelarian diri (retreat) menuju dan kembali (return) ke alam pedesaan atau ke kehidupan masa lampau(Gifford, 1999: 1-2). Narasi apokaliptik berbentuk sebuah wahyu tentang akhir sejarah. Tema dasar apokaliptik biasanya sebuah perjuangan antara yang baik dan jahat. Apokaliptisisme digambarkan sebagai genre yang lahir dari sebuah krisis, yang dirancang untuk memperkuat tekad dari komunitas yang terpinggirkan dengan memberikan harapan dan visi kebebasan dari keterbelengguannya. Sastra apokaliptik merupakan sastra bawah tanah, hiburan bagi yang teraniaya (Thompson 1997: 13-14).

Bentuk pastoral meliputi (1) bucolic "penggembala" dan tentang lingkungan pedesaan yang melingkupinya; (2) konstruksi arcadiayaitu cara hidup yang diidealkan atau tempat yang diidealkan, terdiri dari tiga unsur yaitu Idylls yang memuat deskripsi idealisasi nilai-nilai desa yang mengimplikasikan kritisisme kota, unsur Nostalgia, sebagai bentuk yang selalu melihat ke belakang atau ke masa lalu dan unsur Georgic yang menampilkan kenyamanan bekerja secara harmonis dengan alam; (3) retreat dan returnmeliputi .Wacana retreat yang secara sederhana berarti pelarian dari kompleksitas kota, orang-orangnya, masa kini, ,tingkah laku kita ${ }^{\text {ee, }}$ „mengeksplorasi ${ }^{\text {ee }}$-nya (Gifford, 1999: 45-46).Return berbentuk pelarian diri dari kota ke desa atau menyadari bahwa lingkungan alam seperti pedesaan, hutan, dan gunung dapat memberikan ketenangan dan pengayoman. Namun dapat juga berbentuk pelarian diri fisik menuju penemuan diri psikis (retreat sekaligus return).

Karakteristik sastra apokaliptik antara lain (1) penulis cenderung memilih beberapa orang besar atau tokoh berpengaruh di masa lalu dan membuatnya menjadi sosok yang berjasa dalam cerita; (2) sosok pahlawan yang sering melakukan perjalanan; (3) adanya pemandu surge yang menunjukkan suatu 
pemandangan yang menarik; (4) penulis sering mengambil sejarah masa lalu; (5) unsur yang mengandung kilasan tentang dunia yang berubah; (6) upaya persuasif untuk mencegah akhir dunia; (7) kesadaran manusia melakukan hal terbaik dengan mengakui keajaiban alam; (8) kesadaran penolakan terhadap godaan memaksakan kehendak atas alam(Janik 1995: 107).

Model kajian etis mencakup etiket lingkungan atau (nilai) kearifan lingkungan. Etiket berisi tentang nilai dan prinsip moral yang dianut oleh masyarakat tertentu sebagai pedoman dan kriteria dalam berperilaku sebagai manusia. Pada umumnya, sistem nilai, yang dipelihara sebagai sebuah kebiasaan hidup yang baik, diturunkan dan diwariskan melalui agama dan kebudayaan, yang dianggap sebagai sumber utama norma dan nilai moral (Keraf, 2010: 14-16).

Menurut Amrih, etiket memerlukan sarana dan media ekspresi. Sarana ekspresi etiket dapat berupa bahasa, dan aspek nonbahasa. Etiket yang terekspresikan melalui bahasa beragam wujudnya, misalnya dapat berwujud karya sastra. Karena karya sastra dapat mengisahkan kehidupan atau perilaku manusia, nilai-nilai yang dianut oleh masyarakat terdapat pula di dalamnya. Salah satu perwujudannya adalah etiket lingkungan atau (nilai) kearifan lingkungan. Kearifan lingkungan merupakan sebuah kesadaran untuk menjadi bagian dari alam sehingga tercipta satu kesatuan harmoni (Amrih, 2008:33).

Kearifan lingkungan bewujud prinsip-prinsip moral berupa sikap hormat terhadap alam (respect for nature), sikap tanggung jawab terhadap alam (moral responsibility for nature), solidaritas kosmis (cosmic solidarity), prinsip kasih sayang dan kepedulian terhadap alam (caring for nature), prinsip tidak merugikan alam (no harm), prinsip hidup sederhana dan selaras dengan alam; prinsip keadilan; prinsip demokrasi; dan prinsip integritas moral (Keraf, 2010).

Kumpulan puisi Kidung Cisadane karya Rini Intama tidak hanya puisi yang bertema tentang budaya dan sejarah dari kota Tangerang, tetapi juga perhatian terhadap lingkungan di sekitar kota tersebut terutana sekitar sungai Cisadane. 
Bertolak dari pendapat Gifford di atas, penelitian ini bertujuan untuk mendeskripsikan sastra lingkungan yang meliputi kajian pastoral dan apokaliptik serta kajian etis yang mengandung kearifan lokal pada kumpulan puisi Kidung Cisadane karya Rini Intama.

\section{Metode Penelitian}

Sumber data penelitian ini adalah kumpulan puisi Kidung Cisadane karya Rini Intama. Buku antologi puisi tersebut terbagi menjadi dua bagian, bagian pertama berjudul Kidung Cisadane terdiri dari 43 puisi yang keseluruhannya menceritakan sejarah dan budaya Tangerang serta alam yang melingkupinya, sedangkan bagian kedua berjudul Aubade terdiri dari 23 puisi berisi tentang berbagai tempat di Nusantara. Dari semua puisi tersebut, yang dikaji hanya bagian pertama (43 puisi) yang berjudul Kidung Cisadane.

Penelitian ini termasuk penelitian kualitatif dengan menggunakan metode penelitian deskriptif kualitatif dengan cara mendeskripsikan fakta-fakta yang ditemui, disusul dengan analisis (Ratna, 2007: 53). Menurut Krebs (dalam Leksono, 2007:7) Pendekatan deskriptif dimanfaatkan untuk mendeskripsikanunsur-unsur ekologis dalam karya sastra. Pendekatan fungsional dimanfaatkanuntuk menganalisis cara unsur-unsur ekologi ada karya sastra. Pendekatan evolusidimanfaatkan untuk menganalisis sebab-sebab unsur-unsur ekologi ada dalamkarya sastra. Jadi, ketiga pendekatan tersebut dapat digunakan menganalisis aspekekologis dalam karya sastra secara komprehensif.

\section{Pembahasan}

Puisi yang berlatar budaya dan sejarah bukanlah hal yang baru. Kumpulan puisi Kidung Cisadanekarya Rini Intama berisi 65 puisi yang terbagi menjadi dua.Bagian pertama berjudul Kidung Cisadane dan bagian kedua berjudul Aubade. Dalam kajian ekokritik ini, dipilih kumpulan puisi yang pertama karena bertema budaya 
dan sejarah Tangerang.Puisi-puisi tersebut dibaca dan dipilah-pilah sesuai kajian sastra lingkungan dan kajian etis (etiket lingkungan atau (nilai) kearifan lingkungan).

\section{Kajian Pastoral}

Unsur Nostalgia, sebagai bentuk yang selalu melihat ke belakang atau ke masa lalu menjadi warna dalam kumpulan puisi Kidung Cisadane karya Rini Intama. Unsur ini mencakup 70\% dari jumlah yang ada (43 puisi). Hal ini memang berkaitan tentang tema puisi-puisi tersebut yaitu sejarah dan budaya Tangerang. Namun, unsur Nostalgia juga dipadu oleh unsur yang lain seperti Georgic, Idylls, Bucolic, Retreat, dan Return.

\section{Masjid Jami Kalipasir}

Abad tujuhbelas yang membekas sunyi, di lembaran waktu kota ini Mengetuk ingatan tentang syiar Islam berabad silam Perahu kecil berlayar menuju lekuk tubuh sungai dan belukar Dari kahuripan tanah makmur, hingga di bantaran cisadane sebelah timur Membangun altar kebesaran, atas nama Tuhan yang mengirim pesan

Di tanah pecinan empat tiang kayu menyangga kubah bergambar teratai Ada percakapan bulan dan cahaya semesta di atas dua makam tua Aksara ayat di empat penjuru angin Di sinilah bibit-bibit perjuangan tersemai

Kitab Tuhan dan suara azan dari menara mesjid bersujudlah langit dan bumi Melintasi alam pagoda dan ekor naga adalah cahaya yang memandang langit 2016:4)

Di peradaban tua, manusia tetap saling mencinta hingga ke surga (Intama,

Kutipan puisi di atas mengandung unsur Nostalgia yaitu Abad tujuhbelas yang membekas sunyi, dilembaran waktu kota ini, serta Mengetuk ingatan tentang syiar Islam berabad silam. Penulis melihat masa lampau saat syiar Islam dimulai pada abad 17 di Kota Tangerang. Larik puisi yang mengandung unsur Georgic yaitu Perahu kecil berlayar menuju lekuk tubuh sungai dan belukar. Dalam larik tersebut 
terdapat kenyamanan manusia berinteraksi dengan alam yang masih asri belum terusik oleh tangan manusia. Manusia membutuhkan alat transportasi baik di darat maupun di air. Tubuh sungai yang masih belukar merupakan sarana transportasi saat itu.

Unsur Bucolic yang berkaitan dengan "penggembala" atau unsur lingkungan yang masih asri belum terjamah manusia ada pada kata "belukar", sedangkan unsur Return ditandai pada larik Dari kahuripan tanah makmur, hingga di bantaran cisadane sebelah timur. Dari judul puisi tersebut yaitu Masjid Jami Kalipasir, dapat diketahui bahwa mssjid dibagun oleh seorang Tumenggung dari Bogor dan pemilihan lokasinya adalah sebelah timur bantaran sungai cisadane, bukan di pusat kota. Hal ini menandakan bahwa manusia menyadari bahwa lingkungan alam di sekitar sungai memberikan ketenangan.

Unsur Idylls yang mengarah pada cara (tempat) hidup atau nilai-nilai yang diidealkan terdapat dalam larik Kitab Tuhan dan suara azan dari menara mesjid bersujudlah langit dan bumi. Melintasi alam pagoda dan ekor naga adalah cahaya yang memandang langit. Di peradaban tua, manusia tetap saling mencinta hingga ke surga. Dari larik tersebut dapat diketahui adanya kebersamaan, toleransi, saling menghormati, dan menghargai karena pembangunan Masjid Jami Kalipasir berada di tanah pecinan bahkan bersebelahan dengan klenteng.

Dalam puisi berjudul $A$ Yin, penulis mengisahkan perjuangan perempuan suku Tionghoa mempertahankan tanah, adat, tradisi, serta menghadapi perubahan kehidupan yang mengarah pada deskriminatif agama dan suku.

ketika tarian cokek sudah dimulai berganti demo buruh ketika bulir-bulir padi juga sungai kecilnya telah berbau limbah ketika petak-petak sawahnya sudah tergilas suara-suara mesin bertahun lalu dan ketika bilik rumahnya telah bertambal kertas-kertas kebohongan (Intama, 2016: 27).

Kutipan puisi di atas mengandung unsur pastoral bucolic yang menunjukkan gambaran sawah serta padi yang sudah berisi.

A Yin tetap mencari jalan pulang dan menembang kidung-kidung Yang mengirimkan cahaya-cahaya lilin merah yang benderang 
Sejak mula dari pesisir Tanjung Kait dan aroma laut Tanjung Pasir Hingga jalan-jalan setapak sepanjang Cisadane

Dari kutipan puisi di atas, terdapat aspek return dari tempat yang luas (Tanjung Kait dan Tanjung Pasir) hingga jalan-jalan setapak sepanjang Cisadane. Hal ini menunjukkan lingkungan alam yang dirindukan, ingin return kembali ke desa. Sebuah nostalgia perjalanan hidup di ladang (unsur bucolic) terdapat pada kutipan selanjutnya di bawah ini.

A Yin terus menulis kisah Cina benteng Di atas batu juga tanah ini dan kelopak mawar yang menyimpan embun sunyi Entah berapa langit dan perjalanan sejarah yang menyimpan ribuan kisah

Di ladang, di lembaran-lembaran sajak, di tiang-tiang dan benteng kota Hingga tanah gocap dan nisan-nisan diam terbelah (Intama, 2016: 27).

Unsur bucolic (lingkungan pedesaan) juga terdapat dalam kutipan puisi yang berjudul Sajak buat Goen seperti berikut ini.

Di pelataran rumahmu yang teduh, Burung-burung dara terbang bersama, pepohonan punya kisah tentang belandar utama

Harumnya ruang paseban dan senyum tetemu, juga latar luas tempat padi dijemur matahari (Intama, 2016: 10).

Rumah-rumah pedesaan memang mempunyai latar yang luas.Latar ini digunakan untuk menjemur hasil panen seperti padi, cengkih, lada, dan sebagainya.

Dalam puisi A Yin, meskipun perempuan-perempuan seperti A Yin semakin tersingkir, ada cara hidup atau nilai perjuangan yang diidealkan (termasuk konstruksi Arcadia berbentuk unsur Idylls). Hal ini terlihat dalam larik puisi di bawah ini yang menyatakan bahwa A Yin tetap menyiapkan tahun baru imlek yang selalu ditunggu dengan membuat kue keranjang.

A Yin terus menunggu pijar-pijar kembang api

Lalu katanya, aku masih membuat kue-kue keranjang dan secangkir teh hangat (Intama, 2016: 4). 


\section{Kajian Apokaliptik}

Kajian apokaliptik meliputi unsur karakter pahlawan atau orang yang telah berjasa dan unsur lingkungan apokaliptik yang meliputi (1) narasi yang mengandung kilasan tentang dunia yang berubah; (2) upaya persuasive untuk mencegah akhir dunia; (3) kesadaran manusia melakukan hal terbaik dengan mengakui keajaiban alam; (4) kesadaran penolakan terhadap godaan memaksakan kehendak atas alam.

Kajian Apokaliptik yang mempunyai ciri memilih tokoh atau seseorang yang mempunyai jasa pada zamannya terdapat dalam kumpulan puisi KidungCisadane ini.Hal ini dapat dilihat dari kutipan puisi berikut ini.

Rumahmu Kini

: Kapitan Oei Dji San

Dua abad rumahmu di persimpangan Karawaci

Bercerita soal Si He Yuan, ladam kuda si penyangga cinta

Pada tiang kayu dan batu-batu zaman peradapan yang dingin

Aku membaca soal rumah besarmu yang kau tinggalkan

Tanpa pesan di dinding rumah atau pada batu nisan

Juga di perkebunan karetmu yang luas (Intama, 2016: 2).

Dari kutipan puisi di atas, ada sosok Kapitan Oei Dji San sebagai tokoh yang merawat, mengelola dengan baik perkebunan karet yang luas. Selain itu, tokoh tersebut memiliki rumah-rumah panjang yang mengandalkan alam yaitu kayu dan batu.

Contoh lain yang menggambarkan perhatian tokoh terhadap alam dan relasinya dengan manusia terdapat dalam kutipan puisi berikut ini.

Kidung Tanah Partikelir

: 1924

Padamu Kalin bin Bayah. Kampung Pangkalan Teluk Naga di atas tanah partikelir pinggir kota. Bujang sawah menggarap air mata memilin dada di sawah hingga perkebunan sutera.Sejak daun dan bunga bunga bermekaran melintasi musim. Sejak Tuan tuan tanah mengunjungi matahari, menenteng tas kulit bercahaya berisi nafsi yang membelit (Intama, 2016: 13). 
Dalam puisi Kidung Tanah Partikelir, sosok yang dituju dalam puisi tersebut adalah Kalin bin Bayah, tokoh pemberontakan petani yang melawan tuan tanah. Tokoh ini memperjuangkan hak petani.

Dalam kumpulan puisi Kidung Cisadane karya Rini Intama ini, kajian apokaliptik yang paling banyak adalah tentang kesadaran manusia untuk melakukan hal terbaik dengan mengakui keajaiban alam (58\%) serta kilasan tentang dunia yang berubah (42\%). Contoh tentang kesadaran manusia untuk melakukan hal terbaik dengan mengakui keajaiban alam terdapat dalam kutipan puisi Tanjung Kait di bawah ini.

Angin membawa kisah lautku yang biru

Suara kepak camar yang terbang dari pulau ke pulau

Dari pesisir utara, selatan hingga pantai ujung timur 29).

Nelayan mengeja aksara laut di malam yang tak pernah tidur (Intama, 2016:

Dari kutipan tersebut dapat dilihat bahwa manusia (nelayan) sudah menyadari akan tanda-tanda alam seperti arah angin, perubahan cuaca, gelombang laut, dan sebagainya.

Hal tentang keajaiban alam juga terdapat dalam kutipan puisi yang berjudul Di Jalan-Jalan Sunyi.

Di jalan-jalan sunyi

Suara nyanyian gembala seperti terpasung nurani

Aku mendengarmu berkata, sebentar lagi akan datang awan cumulus Bergumul-gumul

Mengirimkan berita soal cuaca yang akan tetap panas (Intama, 2016: 38).

Dalam kutipan puisi tersebut, manusia menyadari akan tanda-tanda alam seperti jenis awan yang akan mendatangkan cuaca meskipun kadang cuaca pun tidak dapat ditebak dengan pasti.

Unsur lingkungan apokaliptik yang mengandung kilasan tentang dunia yang berubah terdapat pada contoh kutipan puisi Simpan Saja Dukamu di bawah ini. 
Mari kita simpan kedukaan

Di mana kita menanam harapan

Di mana ada cinta berkilauan

Aku akan memilih keheningan

Karena hidup dibius peradapan (Intama, 2016: 46).

Dari puisi yang terdiri atas lima larik di atas, dapat diketahui bahwa dunia sangat cepat berubah. Dalam perubahan itu kadang ada rasa kecewa. Namun, akhirnya manusia kembali pada keheningan. Kehidupan manusia cepat berubah, tetapi tidak memperhatikan dampaknya bagi lingkungan seperti dalam kutipan puisi Surat Akar pada Daun di bawah ini.

...sedang kini tanah berlantai beton, mereka membuang helai daun bertonton.Kita kehabisan waktu, menghitung hujan panas dan rasa rindu.Hanya pilar-pilar baja, yang berdoa dalam pot-pot bunga.Sedang pohon rimbun yang tinggi, tak kembali ke bumi (Intama, 2016: 43).

Perubahan dunia tidak hanya berkaitan dengan perubahan fisik saja, tetapi juga perubahan sikap, mental manusia baik relasi dengan sesamanya maupun dengan alam sekitarnya.Hal ini terlihat dalam puisi A Yin di bawah ini.

ketika tarian cokek sudah dimulai berganti demo buruh ketika bulir-bulir padi juga sungai kecilnya telah berbau limbah ketika petak-petak sawahnya sudah tergilas suara-suara mesin bertahun lalu dan ketika bilik rumahnya telah bertambal kertas-kertas kebohongan (Intama, 2016: 27).

\section{Kajian Etis (Nilai Kearifan Lingkungan)}

Kearifan lingkungan yang berwujud prinsip-prinsip moral dalam kumpulan puisi Kidung Cisadane mengacu pada sikap solidaritas manusia pada alam sebanyak $70 \%$ dan sikap tanggung jawab moral manusia terhadap alam sebanyak 30\%. Contoh aspek yang mengacu pada sikap solidaritas manusia pada alam terdapat dalam kutipan puisi Kota Tua di bawah ini.

Di kota ini, dermaga tua tepian Cisadane menyimpan kisahnya

Air mengalir serupa kidung rindu sang bunda

Dan aroma melati makam pahlawan di tengah kota 
Menabur nyanyian klasik para tetua tentang tanah-tanah yang merdeka (Intama, 2016: 6).

Dalam kutipan puisi di atas, manusia turut merasakan alam, yaitu suara air sungai Cisadane yang mengalir, yang menyerupai sebuah kidung rindu pada sang bunda. Gemericik suara air membuat manusia merasa nyaman, tenang, dan sejuk.

Manusia selalu butuh kedamaian, kenyamanan, ketenangan dalam kehidupannya. Manusia selalu mencari semua itu pada alam. Hal ini pun diungkapkan dalam puisi Sajak Buat Goen seperti di bawah ini.

Di sini, di rumahmu yang teduh

Aku mencium aroma alam dan air yang tak pernah mengeluh

Karena di atas daun-daun kering kau selalu menulis, betapa aku mencintai tanah ini (Intama, 2016: 10).

Dalam puisi di atas, manusia menunjukkan sikap solidaritas terhadap alam.Manusia sebetulnya mampu mendeteksi alam dengan melihat, mendengar, serta mencium alam sekitar. Namun, kadang manusia lupa memperhatikan alam.

Sikap tanggung jawab moral manusia terhadap alam ditunjukkan dalam kutipan puisi Kidung Cisadane berikut ini.

Sejak titah kerajaan, mengirimkan perahu dan pendayung sampan nurani

Hingga air dan ikan-ikan terbakar matahari, sedang limbah tak mengenal (Intama, 2016: 20).

Dari kutipan tersebut dapat diketahui bahwa sejak terjadi perdagangan dari satu kerajaan ke kerajaan lain, trasportasi yang digunakan saat itu adalah sungai. Oleh karena itu, banyak manusia yang melewati sungai tersebut tidak memperhatikan kelestarian lingkungan sehingga banyak sampah serta limbahnya.

Sebuah peringatan untuk manusia dari puisi yang berjudul Rumah Tanpa Pohon tentang bagaimana jika bumi yang merupakan rumah kita tidak ada pohon. Apa yang terjadi seandainya pepohonan tidak ada di bumi ini.

Rumah Tanpa Pohon

Bersama debu nafas kita berebut sesak Menangisi kenangan soal daun yang berserak 
Mimpi-mimpi berlompatan

Laksana kembara merindu hutan

Sedang pucuk-pucuk pohon bersembunyi

Sebelum subuh pecah terbakar matahari

Lalu kita mati dengan darah berbau anyir

Dan bibir-bibir pecah kehabisan air (Intama, 2016: 44).

Dalam puisi di atas diekspresikan bagaimana jika tidak ada pohon di kehidupan ini, manusia akan mati. Dalam puisi itu pun digambarkan saat kita mati pun akan terus berbau anyir dan tergambar bibir-bibir manusia yang pecah karena tiada air.

\section{Simpulan}

Kumpulan Puisi Kidung Cisadane karya Rini Intama, tidak hanya merupakan puisi yang berlatar sejarah dan budaya Tangerang saja tetapi juga sarat dengan hubungan manusia dengan alam. Meskipun bertolak dari Cisadane, sebuah sungai yang menggambarkan keterikatan antara manusia dengan alam, penggambaran unsur pastoral dan unsur apokaliptik sangat tajam. Oleh karena puisi ini bertema sejarah, unsur pastoral yang berbentuk Nostalgia sangat dominan. Namun, terdapat pula unsur Georgic 20\% serta unsur Bucolic 10\%. Unsur Georgic menyangkut keharmonisan manusia dengan alam (saling melengkapi), sedangkan Bucolic merupakan bentuk pedesaan dan lingkungannya. Kajian Apokaliptik meliputi kesadaran manusia untuk melakukan hal terbaik dengan mengakui keajaiban alam $(58 \%)$ serta kilasan tentang dunia yang berubah (42\%). Kajian etis atau nilai kearifan lingkungan yang mengacu pada sikap solidaritas manusia pada alam sebanyak $70 \%$ dan sikap tanggung jawab moral manusia terhadap alam sebanyak $30 \%$. Budaya dan sejarah Tangerang yang diekspresikan Rini Intama dalam Kidung Cisadane dikaitkan pula dengan keterikatan manusia dengan alam dahulu hingga sekarang yaitu ketika dunia semakin berubah. 


\section{Daftar Pustaka}

Buell, Lawrence. 1995. The Environmental Imagination. Cambridge: Harvard University Press.

Endraswara, Suwardi dkk. (Ed.) 2013. Folklor dan Folklife dalam Kehidupan Modern: Kesatuan dan Keberagaman. Yogyakarta: Pustaka Timur.

Endraswara, Suwardi. 2016. Sastra Ekologis Teori dan Praktik Pengkajian. Yogyakarta: Caps.

Janik. Del Ivan. 1995. Environmental consciousness in modern literatu: four representative examples ${ }^{\mathrm{ee}}$, dalam G Sessions (ed.) Deep Ecology for the 17 Twenty-First Century: Reading on the Philosophy and Practice of the New Environmentalism. London: Shambhala.

Keraf, A.S. (2010). Etika lingkungan hidup. Jakarta: Penerbit Buku Kompas.

Leksono, Amin Setyo. 2007. Ekologi: Pendekatan Deskriptif dan Kuantitatif. Malang: Bayumedia Publishing.

Garrard, Greg. 2004. Ecocriticism. London and New York: Routledge.

Gifford, Terry. 1999. Pastoral. New York and London: Routhledge.

Glothfelty, C dan H. Froom (eds.). 1996. The Ecocriticism Reader: Landmarks in Literary Ecology. London: University of Goergia Press.

Thompson, D. 1997. The End of Time: Faith and Fear in the Shadow of the Millenium. London: Minerva. 